\title{
Tomato Production Influenced by Variety, Irrigation and Organic Fertilization
}

\author{
Carmen INCULET, Madalina DACHI, Ana GAFINCU, Mirabela GACHE, Gabriel Ciprian TELIBAN, Vasile \\ STOLERU
}

Department of Horticulture, "Ion Ionescu de la Brad" University of Agricultural Sciences and Veterinary Medicine, 3 M. Sadoveanu, code 700440, Iasi, Romania

*corresponding author: vstoleru@uaiasi.ro

BulletinUASVM Horticulture 76(1) / 2019

Print ISSN 1843-5254, Electronic ISSN 1843-5394

DOI:10.15835/buasvmcn-hort: 2018.0037

\begin{abstract}
Tomato (Solanum lycopersicum L.) is one of the most cultivated crops in the world, offering many opportunities for research and marketing also. High productions, in conditions of economic sustainability and assured food safety, can only be achieved through the rational use of cultivation technologies, irrigation, fertilization and use of some cultivars with potential genetically performances. To achieve this goal, the present experiment focused on studying the influence of four tomato cultivars (Siriana $F_{1}$, Minaret $F_{1}, H T P F_{1}$ and Inima de bou), in two irrigation regimes (5200 respectively $7800 \mathrm{~m}^{3}$ ) under chicken drops fertilizer compared with a non-fertilized control. The treatments used induced the increase of the fruit number per plant, ranging from 18 to $65 \%$, statistically significant results $(p<0.05)$ being obtained with the organic fertilizer on Minaret cultivar and the higher water quantity, compared to the control version. The highest production was obtained in the HTP $F_{1}$ cultivars under organic fertilization and $7800 \mathrm{~m}^{3} /$ ha irrigation.
\end{abstract}

Keywords: chicken manure, yield, cultivars, water regime

\begin{abstract}
Introduction
Tomatoes are the most cultivated and consumed vegetables worldwide. High consumption is determined by the fact that these vegetables are the most balanced from a nutritional point of view (Guil-Guerrero and Rebolloso-Fuentes, 2009; Butnariu and Butu, 2014; Jędrszczyk and Ambroszczyk, 2016). Although they are the most appreciated vegetables, studies and researches on this species have not fully constructed the correlation of production with the physical and biochemical quality of the yield, under organic farming conditions (Gonzales and May, 1994; Stoleru et al., 2007).

Tomatoes which are consumed fresh, must have a special taste and colour, some firmness of the pulp and sometimes a certain size of fruit according to the preference of the consumer (Ciofu et al., 2004).
\end{abstract}

If for conventional tomato crops are established means and techniques of obtaining products, for organic farming many of the inputs that supply nutrients are missing. In accordance with EU Regulation 834/2007 all synthetic products are prohibited in organic farming.

In recent times, special attention is given to cultivation with a high duration of fresh fruits. Not the same criteria are required for industrialization where size and shape are of reduced importance, low husks and seeds, a high dry matter, and a low acidity should be requested instead (Toor and Savage, 2004; Toor et al., 2006; Jędrszczyk and Ambroszczyk, 2016). Although countless researches have been done with regard to the quantitative and qualitative improvement of the tomato yield, there still remain undefined the technological measures, which ensure consumer safety and sustainability of the producer. The 
Table 1. Tomato plant height $(n=3)$

\begin{tabular}{|c|c|c|c|c|}
\hline No. & Treatments & Plant height $(\mathrm{cm})$ & Fruit per plant & Fruit weight (kg) \\
\hline 1. & S x 0 x IR5200 & $199.45 \pm 3.12 \mathrm{ab}$ & $21.41 \pm 2.1 \mathrm{a}$ & $0.160 \pm 0.001 \mathrm{a}$ \\
\hline 2. & S x $0 \times$ IR 7800 & $208.26 \pm 5.26 \mathrm{~b}$ & $23.04 \pm 3.32 \mathrm{a}$ & $0.174 \pm 0.002 \mathrm{~b}$ \\
\hline 3. & S x Mt x IR 5200 & $191.31 \pm 1.4 \mathrm{a}$ & $13.56 \pm 1.08 \mathrm{a}$ & $0.168 \pm 0.001 \mathrm{~b}$ \\
\hline 4. & S x Mt x IR 7800 & $197.5 \pm 4.02 \mathrm{ab}$ & $15.52 \pm 1.56 \mathrm{a}$ & $0.171 \pm 0.002 \mathrm{~b}$ \\
\hline 5. & M x O x IR 5200 & $152.64 \pm 4.15 \mathrm{~b}$ & $22.00 \pm 1.9 \mathrm{ab}$ & $0.162 \pm 0.002 \mathrm{a}$ \\
\hline 6. & M x O x IR 7800 & $159.76 \pm 3.3 \mathrm{~b}$ & $24.78 \pm 1.45 \mathrm{~b}$ & $0.178 \pm 0.002 \mathrm{~b}$ \\
\hline 7. & M x Mt x IR 5200 & $133.31 \pm 3.16 \mathrm{a}$ & $17.04 \pm 2.34 \mathrm{ab}$ & $0.160 \pm 0.001 \mathrm{a}$ \\
\hline 8. & M x Mt x IR 7800 & $148.97 \pm 2.01 \mathrm{~b}$ & $15.00 \pm 1.61 \mathrm{a}$ & $0.165 \pm 0.002 \mathrm{a}$ \\
\hline 9. & HTP x Ox IR 5200 & $170.78 \pm 3.96 \mathrm{a}$ & $24.63 \pm 2.47 \mathrm{a}$ & $0.184 \pm 0.001 \mathrm{a}$ \\
\hline 10. & HTP x 0 x IR 7800 & $175.69 \pm 7.82 \mathrm{a}$ & $25.26 \pm 1.41 \mathrm{a}$ & $0.209 \pm 0.009 \mathrm{~b}$ \\
\hline 11. & HTP x Mt x IR 5200 & $167.06 \pm 3.7 \mathrm{a}$ & $20.74 \pm 2.22 \mathrm{a}$ & $0.173 \pm 0.001 \mathrm{a}$ \\
\hline 12. & HTP x Mt x IR 7800 & $171.97 \pm 5.05 \mathrm{a}$ & $19.52 \pm 2.01$ & $0.183 \pm 0.001 \mathrm{a}$ \\
\hline 13. & IB x 0 x IR 5200 & $201.48 \pm 7.66 \mathrm{a}$ & $19.59 \pm 1.78$ & $0.188 \pm 0.002 \mathrm{a}$ \\
\hline 14. & IB x 0 x IR 7800 & $228.96 \pm 5.01 \mathrm{~b}$ & $20.44 \pm 1.41$ & $0.191 \pm 0.006 \mathrm{a}$ \\
\hline 15. & IB x Mt x IR 5200 & $198.78 \pm 5.06 \mathrm{a}$ & $14.67 \pm 1.1$ & $0.181 \pm 0.002 \mathrm{a}$ \\
\hline 16. & IB x Mt x IR 7800 & $214.49 \pm 3.92 \mathrm{ab}$ & $15.52 \pm 1.57$ & $0.175 \pm 0.003 \mathrm{a}$ \\
\hline
\end{tabular}

Note: Means within each column followed by the same letters are not significantly different according to Tukey test.

Standard errors are given after mean data.

S-'Siriana' $\mathrm{F}_{1}$; M-'Minaret' $\mathrm{F}_{1}$; HTP-'HTP' $\mathrm{F}_{1}$; IB-'Inima de bou'; O-chicken manure; Mt-control. unfertilized; IR5200-

irrigation regime $5200 \mathrm{~m}^{3} /$ ha; IR7800- irrigation regime $7800 \mathrm{~m}^{3} / \mathrm{ha}$

data from the scientific literature highlights the fact that in organic tomato crops, the number of fruits per plant, plant weight and yield are $30-70 \%$ lower than in conventional farming (Bilalis et al., 2018; Albino et al., 2018).

The purpose of the research was to study the influence of varieties, irrigation regime under organic fertilization on the tomato crop, in protected area compared to untreated version, to promote new technics for organic farming.

\section{Materials and methods}

The experience was carried out during 2017 within the experimental station of UASVM Iasi, in subdivided plots with three replications for each version. Each experimental plot comprised 20 harvested plants. Cultivars were represented by: 'Siriana' $\mathrm{F}_{1}$, 'Minaret' $\mathrm{F}_{1}, \mathrm{CHTP}^{\prime} \mathrm{F}_{1}$ and 'Inima de bou'. The fertilization regime consisted of organic fertilized (0) and untreated versions (Mt).

The seedlings used to set up the crop were produced in greenhouses, under controlled conditions, in pots of $8 \mathrm{~cm}$ diameter and 55 days of age, with a density of 31,250 plants/ha. The setting up of the experience was made around April 15, in an individual solar, on a cernozome cambic soil.

The organic factor represented by chicken manure drops - Orgevit $₫ 1000 \mathrm{~kg} / \mathrm{ha}$, was applied to soil in a quantity of $500 \mathrm{~kg}$ at bed preparation and the rest of $500 \mathrm{~kg}$ in two phases of $250 \mathrm{~kg} /$ ha during the first inflorescence and the third inflorescence appearance.

The irrigation regime was represented by two norms, 5200 and $7800 \mathrm{~m}^{3}$ /ha with 26 times, with an irrigation quantity of $200 \mathrm{~m}^{3}$ /ha respectively $300 \mathrm{~m}^{3} /$ ha, applied by drip irrigation, norms considered optimal for protected area crops (Colla et al., 1999; Ciofu et al., 2004).

Cultural measures and plant protection were applied according to organic farming scientific literature (Stoleru et al., 2014; Munteanu, 2003).

The experimental data processing was carried out using specific mathematical and statistical methods. All analyses were carried out in the three replications. Standard deviation $( \pm$ SD) was calculated for each data series as an indicator of DataSet scatter $(n=3)$. For the calculation of the difference in values compared to the control variants the Tukey test was used for a confidence degree of $95 \%(\mathrm{p}<0.5)$ using SPSS version 20.

\section{Results and Discussions}

Regarding the height of plants we have the lowest value for 'Minaret' $\mathrm{F}_{1}$ control, irrigated with $5200 \mathrm{~m}^{3}$ and the maximum for 'Inima de Bou' organic irrigated with $7800 \mathrm{~m}^{3}$.

The lower average height of the 'Minaret' is determined genetically, the $\mathrm{F}_{1}$ 'Minaret' being a hybrid with semi-determined growth. According to this aspect, even within the cultivation, the 


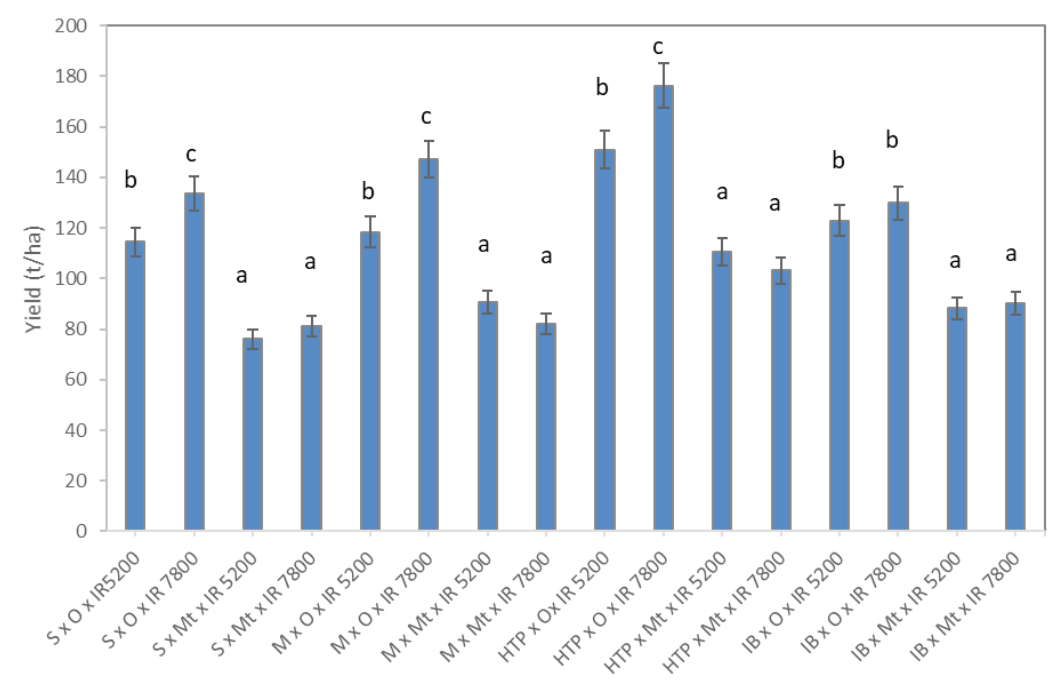

Figure 1. Mean of tomato yield (means \pm standard errors. $n=3$ )

Means within each column followed by the same letters are not significantly different according to Tukey test. S-'Siriana' $\mathrm{F}_{1}$; M-'Minaret' $\mathrm{F}_{1}$; HTP-'HTP' $\mathrm{F}_{1}$; IB-'Inima de bou'; O-chichem manure; Mt-control unfertilized; IR5200- irrigation regime $5200 \mathrm{~m}^{3} / \mathrm{ha}$; IR7800- irrigation regime $7800 \mathrm{~m}^{3} / \mathrm{ha}$

smallest height was in the case of the unfertilized version where the lowest amount of water was used to irrigate.

The most stable hybrid that was not significantly influenced in the height of the plant, regardless the fertilization and irrigation factor was represented by ' $\mathrm{HTP} \mathrm{F}_{1}$, where the differences were very small between the experimental versions (Tab. 1).

The number of fruits per plant varied according to cultivar, irrigation and fertilization regimes. The smallest value have been obtained in the cultivar 'Siriana' $\mathrm{F}_{1} \times \mathrm{Mt} \times 5200 \mathrm{~m}^{3}-13.56$ and the highest in version 'HTP' $F_{1} \times$ organic $\times 7800$ $\mathrm{m}^{3}-25.26$ of organically fertilized cultivation. The smallest value of the growing 'Inimă de bou' $\times$ organic $\times 5200 \mathrm{~m}^{3}-19.59$ and from the control evidence the highest value obtained of 'HTP' $F_{1} \times$ Mt $\times 5200 \mathrm{~m}^{3}-20.74$ (Tab. 1). The only hybrid that ensured statistical differences between control and fertilized variants was 'Minaret' $F_{1}$.

In general, the average fruit weight increased between 1 and $14 \%$ in organically fertilized variants irrespective of the amount of water except for the 'Siriana' variety at which the values were lower for the organically fertilized variant and the low water dose as compared to the control variant (Tab. 1). Significant differences $(p<0.05)$ were obtained in organically fertilized variants and high water regime in 'Minaret', 'Inima de bou' and 'HTP cultivars' $(8,9$ and $14 \%$ respectively).
The highest total yield was achieved by 'HTP' $\mathrm{F}_{1}$ fertilized with chicken drops under $7800 \mathrm{~m}^{3} /$ ha irrigation regime with $176.18 \mathrm{t} / \mathrm{ha}$ and the highest yield in control was obtained by 'Siriana' $F_{1}$ cultivar under $5200 \mathrm{~m}^{3} /$ ha, respectively $76.02 \mathrm{t} / \mathrm{ha}$.

Organicfertilization increased total production of tomatoes in both irrigation regimes (30 to 79\%), a more pronounced increase being observed in high water quantity which increased production in organic fertilized variant statistically significant $(p<0.05)$ at both doses of water compared to the control variants.

However higher values were obtained at the higher dose of water ('Siriana' - 64\%. 'Minaret' 79\%, 'HTP' - 70\% and 'Inimă de bou' - 43\%), while increases in organically fertilized and small doses of water were lower ('Siriana' - 50\%, 'Minaret' 30\%, 'HTP' - 36\% and 'Inimă de bou' - 39\%) (Fig. $1)$. Same results on the influence of the organic fertilizer and the irrigation regime were obtained by Gonzales and May, 1994; Stoleru et al., 2007.

\section{Conclusion}

The research carried out in 2017 revealed that, within the range of tomatoes used, there are significant variations in morphological characters and production.

Cultivars react differently to technological factors on nutrition and irrigation regime.

The height of tomato plants is primarily determined by genetic factors, but within the 
cultivar varies depending also on the fertilizer and the irrigation regime.

The highest number of fruits was achieved in 'HTP' $\mathrm{F}_{1}$ cultivar under organic fertilization and $7800 \mathrm{~m}^{3} /$ ha of water regime.

The highest yield was obtained in 'Minaret' $\mathrm{F}_{1}$ and 'HTP' $\mathrm{F}_{1}$ imported cultivars, under chicken manure fertilizer and high dose of water.

\section{References}

1. Albino VS, Peixoto JR, Caetano V, Vilela MS (2018). Rootstock performance for cherry tomato production under organic greenhouse production system. Horticultura Brasiliera. 36(1):130-135.

2. Bilalis D, Krokida M, Roussis I, Papastylianou P, Traylos I, Cheimona N, Dede A (2018). Effects of organic and inorganic fertilization on yield and quality of processing tomato (Lycopersicon esculentum Mill.). Folia Horticulturae. 30(2): 321-332.

3. Butnariu M and Butu A (2014). Chemical composition of vegetables and their products. Handbook of Food Chemistry in Chemical Composition of Food Commodities. Springer-Verlag Berlin Heidelberg, pp.1-49.

4. Ciofu R, Stan N, Popescu V, Chilom P, Apahidean S, Horgaş A, Berar V, Lauer KF, Atanasiu N, (2004). Tratat de legumicultură. Ed. Ceres. București.

5. Colla G, Casa R, Lo Cascio B, Saccardo F, Temperini O, Leoni $C$ (1999). Responses of processing tomato to water regime and fertilization in central Italy. Acta Horticulturae, 487: 531-536.
6. Gonzales J and May DM (1994). Irrigation and nitrogen management as they affect fruit quality and yield of processing tomatoes. Acta Hortic. 376: 227-234.

7. Guil-Guerrero JL and Rebolloso-Fuentes MM (2009). Nutrient composition and antioxidant activity of eight tomato (Lycopersicon esculentum) varieties. J Food Compos Anal., 22(2):123-129.

8. Jędrszczyk E and Ambroszczyk AM (2016). The influence of NANO-GRO $®$ organic stimulator on the yielding and fruit quality of field tomato (Lycopersicon esculentum Mill.). Folia Hort. 28/1: 87-94.

9. Munteanu, N (2003). Tomatele. ardeii şi pătlăgelele vinete. Editura "Ion Ionescu de la Brad", Iaşi.

10. Stoleru V, Munteanu N, Sellitto VM (2014). New approach of organic vegetable. Publishing Aracnee. Rome. Italy.

11. Stoleru V, Munteanu N, Stan N, Stan C, Stoleru C (2007). The influences of organic fertilization on tomato yield produced in polytunnels in ecological system. Lucrări ştiinţifice vol. 50. seria Horticultură. USAMV Iaşi. pg. 829834.

12. Toor RK, Savage GP (2004). Antioxidant activity in different fractions of tomatoes. Food Research International 38: 487-494.

13. Toor RK, Savage GP, Lister CE (2006). Seasonal variations in the antioxidant composition of greenhouse grown tomatoes. Journal of Food Composition and Analysis 19:110 .

14. UE $834 / 2007$. Organic production and labelling of organic products and repealing Regulation (EEC) No 2092/91. 